\title{
Project Management in the Field of Innovative Technologies of Environmental Management
}

\author{
Galina Potasheva ${ }^{1, *}$ \\ ${ }^{1}$ Moscow State University of Civil Engineering, 129337 Yaroslavskoe sh. 26, Moscow, Russia
}

\begin{abstract}
The article deals with the application of project management in the field of innovative technologies of environmental management. This article examines the sustainability of integrated development environment, and society in the "three ones" concept, which covers all major aspects of development and global change: ecological, social, economic-based planning. But the transition from the national level to the practice of management in the real institutional environment revealed the unresolved systemic issues such as: economic development is considered at the national level; the management of social processes is in the area of responsibility of regions; environmental issues are concentrated at the local, municipal level. To solve this problem, this article discusses the design aspects of environmental management. So in designing the required high degree of understanding of interdependencies and patterns of organizing itself independently of the system that explains the differences between technical and social design. Technical design relies on mechanistic management, while social planning is understood as a system or organic project management. Hence it is safe to state the fact that project management in the environmental management of the country is concentrated in specific design, planning, technical and management solutions, as well as in the creation interested in these effects in all spheres and strata of society.
\end{abstract}

\section{Introduction}

Addressing ensure comprehensive environmental sustainability of the environment and society directly depends on the state and development of investment and construction sector. The value of the investment and construction sector towards sustainable environmental urban development is closely related to environmental management. These areas were engaged in V.V. Asaul, U. Witt, I.P. Nuzhina, A.A. Gorbunov, S.N. Ivanov, A.A. Grebennikov, J.A. Schumpeter, L.E. Bygballe, M. Merklein, M. Anttonen, H. Minna, E. Houtbeckers $[1,2,3,4,5,8,10,12,16]$. Documents for sustainability integrated development environment and society were taken at the level of heads of States and governments for more than 20 years ago at the UN Conference on environment and development (June 1992, Rio de Janeiro). In this, sometimes called "tripod" covers all major aspects of development and global change: ecological, social, economic-based

* Corresponding author: potascheva@mail.ru 
planning. However, the transition from the national level to the practice of management in the real institutional environment revealed the unresolved systemic issues such as: economic development is considered at the national level; the management of social processes is in the area of responsibility of regions; environmental issues are concentrated at the local, municipal level $[7,15]$. In such circumstances, the imbalance of interests of subjects of national, regional and municipal levels in addressing the "three ones" predefined questions. This is a contradiction of conventional development and the real control system with the existing institutions and interests can be solved from the standpoint of design at the scale of the territory or in the time scale $[13,15]$.

\section{Theory}

In designing the required high degree of understanding of interdependencies and patterns of organizing itself independently of the system that explains the differences between technical and social design. Technical design relies on mechanistic management, while social planning is understood as a system or organic project management. Element of project management is its ability to integrate, resulting in increased flexibility (flexibility), which performs set of projects to develop strategies for system - program of projects [6].

Note that in the framework of projects, conflicts might occur, as reflected in the matrix of SWOT - analysis.

\begin{tabular}{|c|c|c|}
\hline Chance & $\begin{array}{l}\text { Risk } \\
\text { Uncertainty at the end }\end{array}$ & $\begin{array}{c}\text { Potential } \\
\text { High probability of success }\end{array}$ \\
\hline The threat & $\begin{array}{c}\text { Potential threats } \\
\text { High chance of failure }\end{array}$ & $\begin{array}{c}\text { Risk } \\
\text { The uncertainty in the completion }\end{array}$ \\
\hline
\end{tabular}

Fig.1. SWOT analysis in project management.

The task of project management is proper assessment of the project, contributing to the achievement of goals. Approach to the project can be regarded as successful if their implementation is taken into account by those who are directly or indirectly related to the project.

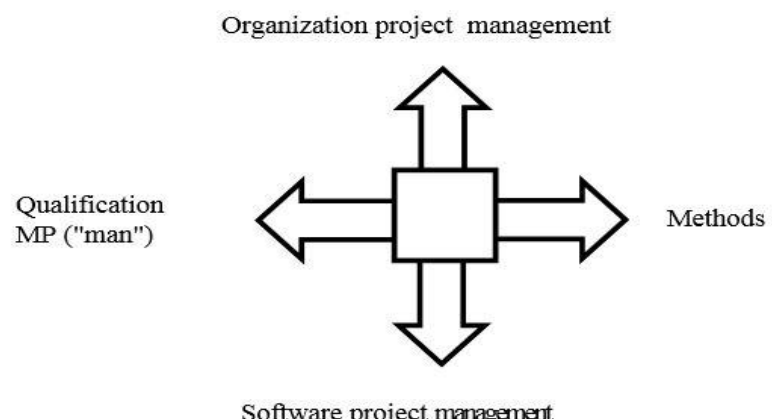

Fig.2.Factors of project management.

Therefore, in project management it is necessary to think not only in the direction of the customer, but primarily in the direction of the user, only then the system can be considered as optimal. Based on the networking of all components and functions of the system occurs systems engineering approach, which allows to achieve internal compatibility between 
system elements and external compatibility. When implementing a systems engineering approach is applied, the hierarchy of the design tasks: the level of social groups (design of municipal services in General); the level of production systems (systems engineering); the level of the subsystems (design of roads); the level of objects (design of specific buildings).

In design it is necessary to consider the classical form of the triple constraints, which reflects the ratio between cost, time and quality of the project [9]. This restriction forms the triangle of project management, where each side represents a constraint as it does not actually carry out the project with minimal time, minimal resources and maximum quality (improving one parameter degrades the other two). Hence the triangle rule States that for each project for a given technical task, there is a boundary triangle. (Fig. 3) The advantage of project management technology is the ability it approaches the boundary limit of the triangle [9].

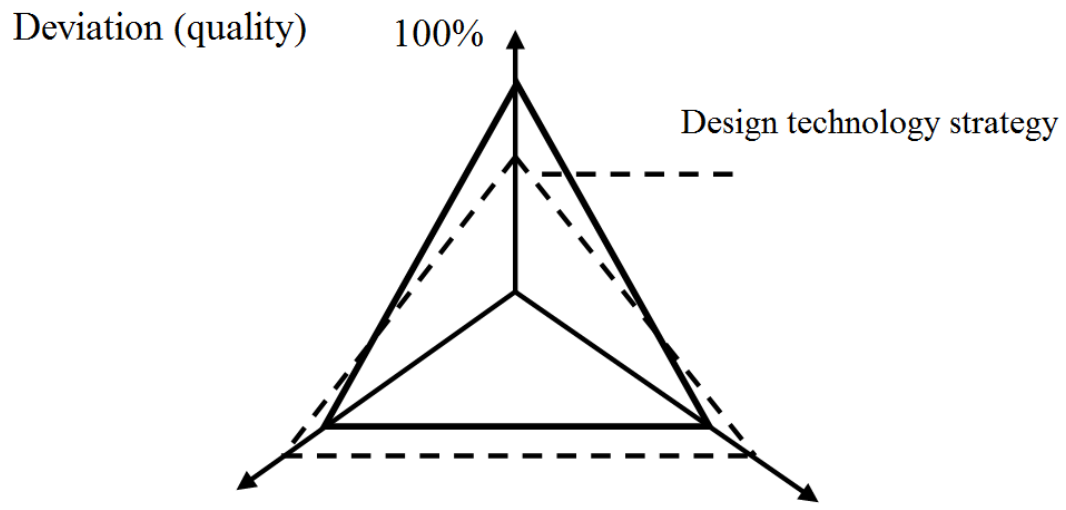

\$ 1 million. budget

4 years time

Fig.3. The triangle of project management

Classical Economics assumes that target aspects may behave as a substitution. However, modern project management requires that these aspects are correlated with each other partially, which would ensure the achievement of several aspects simultaneously. Target the aspects necessary to identify and achieve them within a predetermined corridor of acceptability within which it is possible to marking the upper and lower limits of the reached target aspects. By multiprojective possible simultaneously and in parallel manage multiple projects based on a matrix diagram that illustrates the involvement of the projects in relation to the provision of resources, staff, Finance, infrastructure and so on. The use of multiprojective suitable for those projects that have a very similar background to the implementation and, therefore, are in the nature of repetition.

Table 1. An example of the use of resources in case of implementation of several projects.

\begin{tabular}{|c|c|c|c|c|c|c|c|}
\hline Projects & $\begin{array}{c}\text { Project } \\
1\end{array}$ & $\begin{array}{c}\text { Project } \\
2\end{array}$ & $\begin{array}{c}\text { Project } \\
3\end{array}$ & $\begin{array}{c}\text { Projects } \\
1,2\end{array}$ & $\begin{array}{c}\text { Projects } \\
2,3\end{array}$ & $\begin{array}{c}\text { Projects } \\
2,3\end{array}$ & $\begin{array}{c}\text { Maximum } \\
\text { power }\end{array}$ \\
\hline Resources
\end{tabular}


In the system of project management should be distinguished: a design system as existing parties; the product as the object on which the action is directed; the project itself as a system of action. Project management is a cybernetic process of planning, management and control (Fig. 4).

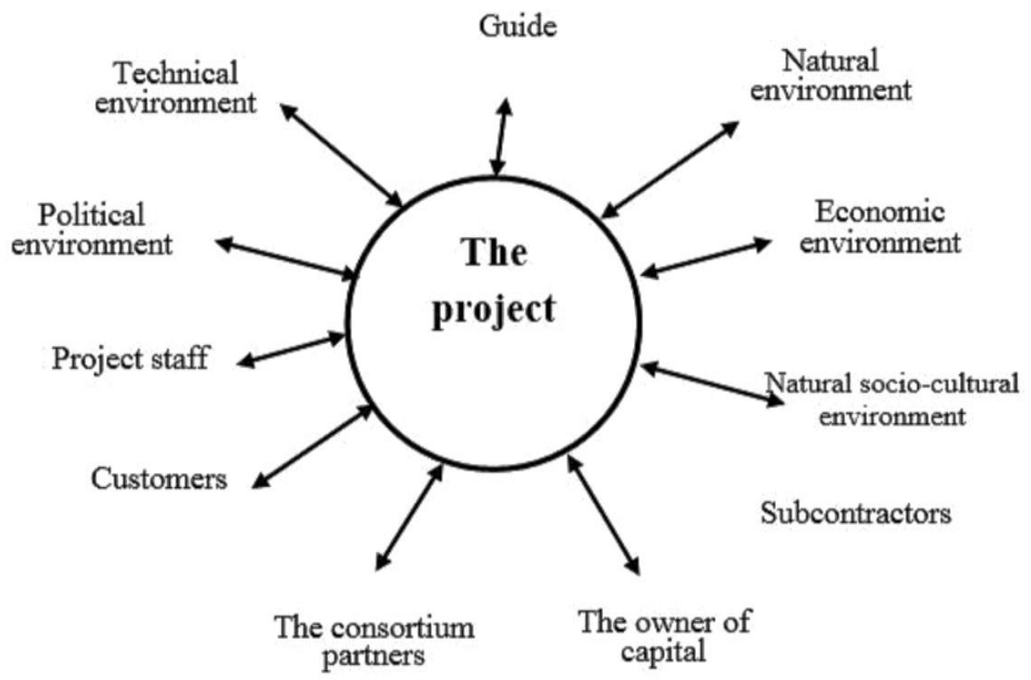

Fig.4. The system model of the relationship between the project system and its environment.

In the design of the following phase (phase - a period of time, which is characterized is characterized by achievement of a certain objective state of the project) - planning and implementation. In the construction industry distinguishes between the following phases: the formation of concepts, design, preparation and execution. The end of each phase is denoted by the so-called main landmark: in podpisac for differentiation can be used intermediate milestones. Phases can overlap each other in order to save preparation time or to provide timely transition into a new phase.

The relationship between project phases and arising costs according to phases is manifested in the fact that in the later phase of the project (production and supply, operation and maintenance) account for a large part of the costs.

In the project management applies the concept of extensive funding exists within the financial design that reflects accurate, specific to each project. Thus, financial engineering is a set of actions to implement financial consultations in the framework of financing the project.

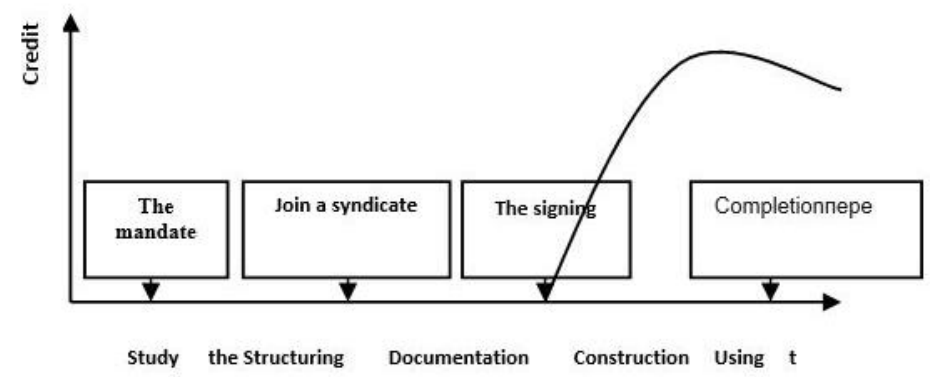

Fig.5. The life cycle of the project. 
There are the following significant "project Phase" in the framework of their financing, which for better understanding in this respect the project duration is subdivided into three main stages:

At the preliminary stage of investment, within the framework of Finance explores the idea of the project and is supported by a market study, profitability study of the project and its technical feasibility.

At the stage of implementation of the investment and the Bank provides the financing concept, which includes a detailed financing structure.

At the stage of operation and use of the project is controlled by the return of funds.

As a special risk of financing the project are the following: the risk in the end; during dismantling risk; operational risk; market risk; political risk. It is obvious that it is necessary to limit the extent of possible risk to the minimum or to find a large number of parties willing to undertake the risks (Fig. 5) [6].
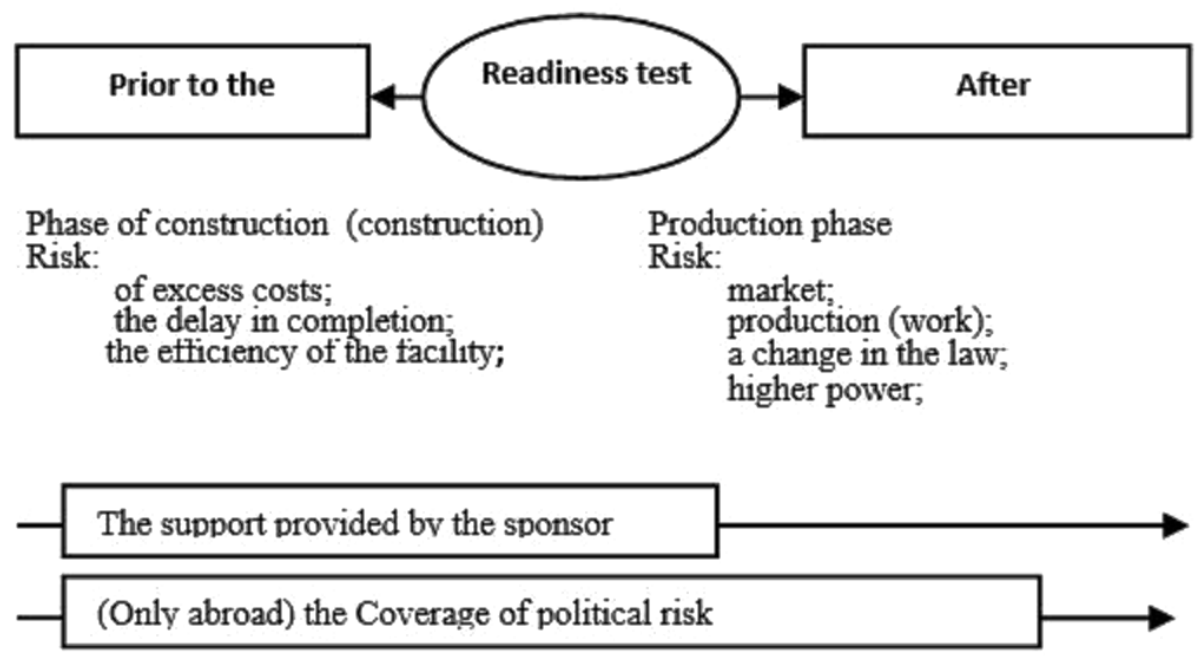

Fig.6. Financing structure of projects and the corresponding risk phases of completion.

The project cycle management - linked to project lifecycle and management objectives. As the main scheme of the model cooperative societies of project management can make the following (Fig. 7).

The project cycle, which underlies the model, is characterized by the following phases: identification; formation concepts; implementation. At these phases as milestones to achieve the next phase are the project idea, project objectives, project plan and its ending.

During the execution phases, decisions on the continuation of the project. Phase processes at certain intervals are characterized by uneven temporal development. The valuation of the project taking into account expenses incurred after the termination of the project, needs to be set against the benefits of its further carrying out. The decision on the termination of the project: KPD - KRA $>$ D, where KPD is the cost of the proposed project; EDGE - costs on the termination of the project; RE - the benefits of the project. If the future benefits from the project is less than the cost of the proposed project net of expenses on termination of the project, the project should be terminated (Fig. 8) [6]. 


\section{COOPERATIVE MODEL RSM}

The levels of technical cooperation

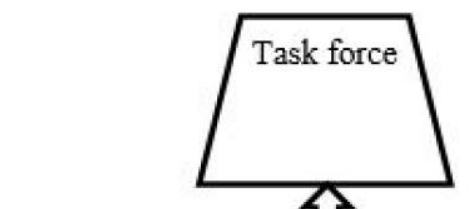

Cooperation

Cooperation

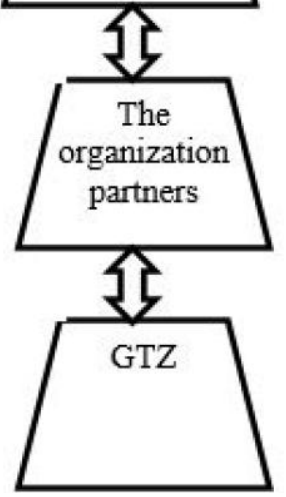

The production process
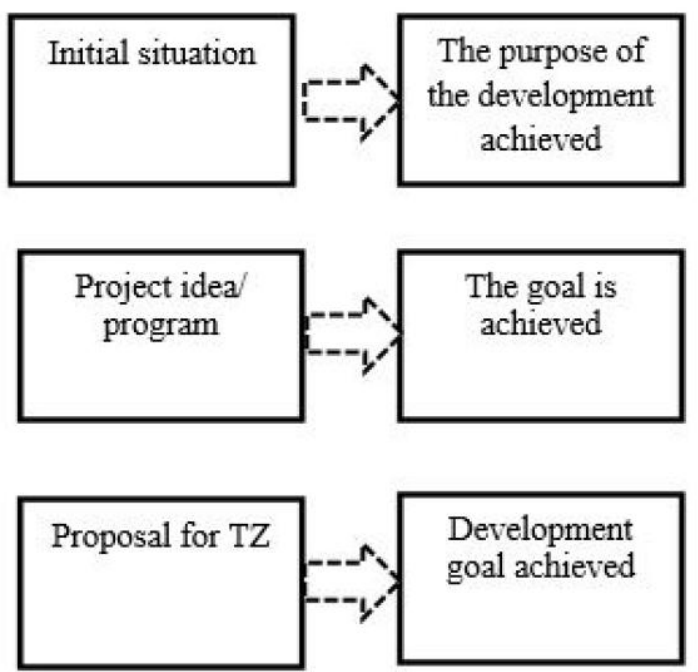

Fig.7. Cooperative management model project cycle.

GTZ - society for technical cooperation

$\mathrm{TZ}$ - technical cooperation

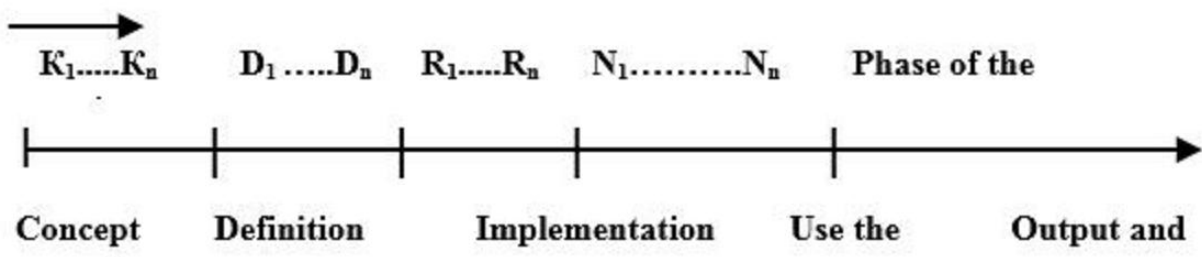

\section{Phase}

Fig.8. Possible milestones the termination of the project.

The planning aspect is Central in the field of project management as it is responsible for work plans, time and cost, for the commercial execution of orders, the preparation of financial statements and traced in the scheme of differentiation of the phases: definition; analysis; design; implementation; system test; acceptance; maintenance.

In the hierarchy of plan creation project management applied in a variety of positions. On the lower level of planned budgets (project expenditures), and the progress of the case at the secondary level. On a higher level through projects implemented strategies and implemented goals: Goals $\rightarrow$ Objectives $\rightarrow$ Strategy $\rightarrow$ Policy: main or auxiliary $\rightarrow$ Procedure $\rightarrow$ the Rules $\rightarrow$ Program: main or auxiliary and support $\rightarrow$ Budget: the program digital indicators.

The need for regulation arises from the deviations that appear as a result of changing the reference position on the basis of incorrect action, or new settings of the project during its implementation [1].

Variance analysis relates to the various hierarchical levels of the project, starting with work package, using the partial projects to the entire project. To prevent possible 
deviations, management needs to respond to the signals coming from the system. In this case, shorter reaction time in project management (Fig. 9).

\begin{tabular}{|c|c|c|c|}
\hline \multirow{2}{*}{ Destination search } & 1 & Analysis of the problem & \multirow{9}{*}{ Planning } \\
\hline & 2 & Statement of purpose & \\
\hline & & & \\
\hline \multirow{3}{*}{ Search solutions } & 3 & Development of alternatives solutions & \\
\hline & & & \\
\hline & 4 & Analysis of alternatives of the solution & \\
\hline \multirow{3}{*}{ Choice } & 5 & Assessment & \\
\hline & & & \\
\hline & 6 & Solution & \\
\hline & 7 & The Dlomping detrito ond menement & \multirow{3}{*}{ Implementation } \\
\hline & & & \\
\hline & 8 & Implementation & \\
\hline & 9 & Control & Control \\
\hline
\end{tabular}

Fig.9. The elements of planning, implementation and control.

In the formation of projects as elements of system development, must adhere to the following principles: investing in research through projects, should seek advantages in price, quality or other characteristics; the results of research are always uncertain, so you need to take into account the probability of success and the amount of potential profit: if the probability of success is high, it makes sense to work on the project; projects with a high probability of success, but with small prospects of recoupment are worth implementing, if the costs are low; if the sales potential is great, and the probability of success of the project is small, this is based on luck or random good fortune.

\section{Insights}

In modern conditions it is safe to state the fact that project management in the environmental management of the country is concentrated in specific design, planning, technical and management solutions, as well as in the creation interested in these effects in all spheres and strata of society $[13,14,15]$.

\section{References}

1. M. Anttonen, H. Minna, E. Houtbeckers, Journal of cleaner production, 45, 89-103 (2013)

2. V.V. Asaul, Scientific bases of the concept of economic innovation strategy building organizations on the basis of integration processes (SPbGSU, $\mathrm{SPb}, 2005$ )

3. U. Witt, The Paperson Economics and Evolution, 0605, (2006)

4. A.A. Gorbunov, S.N. Ivanov, A.N. Asaul, Formation of a regional building complex in transitive economy (Peter Fund, SPb, 1999)

5. A.A. Grebennikov, Regional Economics and Management, 6, (2006)

6. G. Diethelm, Project Management, T1. In 2: volumes (Business - press, SPb, 2004) 
7. The concept of long-term socio-economic development of the Russian Federation until 2020. Information on: www.youngscience.ru

8. M. Merklein, M. Geiger, Journal of materials processing technology, 532-536 (2002)

9. .S.A. Mishin. Project activity: adapted model for Russia (AST, Moscow, 2006)

10. I.P. Nuzhina, Economy of Natural Resources and Conservation: a collection of articles XII International nauch.- Practical. Conf., 23-27 (2009)

11. A. Serpell, R. Alvarez, Procedia Engineering, 85, 464-472, (2014)

12. Information on http://cheltoday.ru/articles/blogi/ustoychivoe-razvitie-iekologicheskaya-polupravda-95668/

13. N. Parthenopoulou, M. Malindretos, Original Research Article Materials Today: Proceedings, 3, 898-912 (2016)

14. S. Bobylev, R. Flights, Sustainable development in Russia (2013)

15. Information on: http://cheltoday.ru/articles/blogi/ustoychivoe-razvitie-iekologicheskaya-polupravda-95668/

16. J.A. Schumpeter, Essays on entrepreneurs, innovations, business cycles, and the evolution of capitalism, Clemence; with a new introduction by Richard Swedberg (Transactions Publishers, London, 1983) 